\title{
RASIO AST/ALT PADA LAKI-LAKI PENGKONSUMSI ALKOHOL DI JALAN MENDAWAI KOTA PALANGKA RAYA
}

\author{
AST/ALT Ratio on Alcohol Consumption Men in Mendawai Street Palangka Raya \\ 1*Dwi Purbayanti, ${ }^{1}$ Muhammad Rizwan Nafarin \\ ${ }^{1,2}$ Department of Medical Laboratory Technology, Universitas Muhammadiyah Palangkaraya, Jl. RTA. Milono \\ Km. 1,5, Palangka Raya, Indonesia \\ *e-mail : dwipurbayanti@gmail.com
}

\begin{abstract}
ABSTRAK
Aspartate aminotransferase (AST) dan Alanine aminotransferase (ALT) merupakan enzim yang terutama ditemukan di hepatosit, peningkatan aktivitasnya di dalam serum menunjukkan adanya kerusakan hati. Rasio AST/ALT digunakan sebagai penanda adanya penyakit hati alkoholik. Penelitian ini bertujuan untuk mengetahui efek dari konsumsi alkohol jangka panjang terhadap risiko penyakit hati alkoholik. Penelitian ini adalah penelitian deskriptif, dengan melibatkan 20 laki-laki peminum alkohol yang berusia 25-45 tahun, telah mengkonsumsi alkohol > 5 tahun dan setiaphari mengkonsumsi alkohol. Hasilpenelitian kami menunjukkan terdapat peningkatan signifikan ( $\mathrm{p}<0.05)$ pada nilai AST dan ALTberdasarkan kelompok usia, lama mengkonsumsi dan dosis. Sedangkan rasio AST/ALT, peningkatan signifikan terdapat pada kelompok usia dan durasi.Pada peminum alkohol, nilai AST lebih besar dibandingkan ALT. Rasio AST/ALT pada peminum berat diperoleh nilai 1,64. Kesimpulan: Subjek pengkonsumsi alkohol dalam penelitian kami terutama peminum berat dicurigai telah memiliki risiko penyakit hati alkoholik karena sebagian besar memiliki rasio AST/ALT >1.
\end{abstract}

Kata kunci : AST, ALT, Rasio AST/ALT, Penyakit hati alkoholik

\begin{abstract}
Aspartate aminotransferase (AST) and Alanine aminotransferase (ALT) are enzymes predominantly found in hepatocytes, the increased activity in the serum shows liver damage. The AST / ALT ratio is used as a marker for alcoholic liver disease. This study aims to determine the effects of long-term alcohol consumption on the risk of alcoholic liver disease. This study was a descriptive study, involving 20 alcoholic drinkers aged 25-45 years, had consumed alcohol> 5 years and consumed alcohol every day. Our results showed a significant increase ( $p<0.05)$ in AST and ALT values based on age group, duration of consumption and dose. While the ratio of AST / ALT, a significant increase was found in the age group and duration. In alcohol drinkers, the AST value is greater than ALT. The AST / ALT ratio for heavy drinkers is 1.64. Conclusion: Alcoholconsuming subjects in our study, especially heavy drinkers, were suspected of having a risk of alcoholic liver disease because most had an AST / ALT ratio> 1.
\end{abstract}

Keyword: AST, ALT, AST/ALT Ratio, Alcoholic liver disease

\section{PENDAHULUAN}

Penyalahgunaan alkohol telah dikaitkan dengan bahaya kesehatan termasuk risiko berbagai penyakit, kesehatan mental, kecelakaan dan disfungsi sosial (WHO, 2018). Penyalahgunaan alcohol kronis dapat menyebabkan penyakit multisistemik dan juga perubahan patofisiologis pada sebagian besar organ, misalnya, sirosis hati, kanker payudara pada wanita, kanker kolon, penyakit ginjal, penyakit pancreas, diabetes, defisiensi system imun, osteoporosis, gangguan pencernaan, hipertensi, penyakit jantung, artritis, dan gangguan system saraf pusat(Dguzeh et al., 2018).
Konsumsi alcohol telah banyak dilaporkan berhubungan dengan prevalensi penyakit hati alkoholik. Alkohol telah terbukti menyebabkan kerusakan hepatoselular melalui mekanisme yang berhubungan dengan metabolisme etanol di hepatosit dan malnutrisi (Gao \& Bataller, 2011).

Alkohol (etanol) yang dikonsumsi, akan dimetabolisme terutama di hati. Proses metabolisme alcohol di hati akan menghasilkan asetaldehid yang bersifat toksik, pembentukan senyawa adduct, defisit oksigen (hipoksia) di hati dan menghasilkan radikal 
bebas yang dapat merusak komponen sel lainnya (King, 2017).

Alkohol adalah salah satu penyebab penyakit hati yang paling sering; termasuk hepatitis alkoholik, steatosis, steatohepatitis, fibrosis dan sirosis (WHO, 2018). Beberapa penanda yang digunakan untuk mengetahui efek dari konsumsi alcohol terhadap penyakit hati seperti alanin transaminase (ALT), aspartat transaminase (AST), gamma glutamil transferase (GGT), dan Mean Corpuscular Volume (MCV) dan Carbohydrate deficiency transferrin (CDT) (Mcdonald et al., 2013)

.Pengukuran aktivitas enzim AST dan ALT di serum, umumnya diminta sebagai bagian dari tes fungsi hati untuk menilai adanya penyakit hati. Pelepasan AST dan ALT dari sel hati ke aliran darah menunjukkan adanya kerusakan sel hepatosit (Shreevastva et al., 2017). Peningkatan AST dapat diamati dalam semua bentuk penyakit hati alkoholik dengan sensitivitas $50 \%$ dan spesifisitas sekitar 80\%.Kadar AST jarang di atas $300 \mathrm{U} / \mathrm{ml}$, sedangkan kadar ALT serum umumnya lebih rendah. Rasio AST/ALT biasanya lebih besar dari 1, meskipun tidak spesifik dan tidak sensitif, terutama pada tahap penyakit sirosis(Thursz et al., 2018).

Hati adalah target organ utama dari toksisitas etanol, yang menyebabkan patologi seperti steatosis (perlemakan hati), peradangan, dan stresoksidatif. Penelitian sebelumnya terhadap 20 orang peminum alcohol di Kecamatan Jekan Raya Kota Palangka Raya diperoleh hasil 95\% peminum alcohol mengalami hipertrigliseridemia (Purbayanti, 2017), dan kondisi ini dapat menjadi factor risiko perkembangan penyakit perlemakan hati alkoholik (Steiner \& Lang, 2017). Penelitian ini bertujuan untuk mengetahui apakah ada risiko penyakit hati pada penyalahgunaan alkohol di kecamatan Jekan Raya Kota Palangka Raya, akibat mengkonsumsi alkohol jangka panjang.

\section{METODE PENELITIAN}

Penelitian ini merupakan jenis penelitian deskriptif. Sampel yang digunakan adalah peminum alkohol di Jalan Mendawai Kota Palangka Raya dengan kriteria inklusi berjenis kelamin laki-laki, berusia lebih dari 20 tahun, sudah mengkonsumsi alkohol lebih dari 5 tahun, mengkonsumsi alkohol setiap hari. Penarikan sampel dilakukan secara Snowball sampling dan diperoleh sebanyak 20 orang peminum alkohol yang akan dijadikan subjek dalam penelitian ini. Pengambilan sampel darah vena dilakukan pada tanggal 14-16 Mei 2018. Sebelum dilakukan pengambilan sampel darah, subjek diminta untuk mengisi informed consent sebagai pernyataan kesediaan mengikuti penelitian. Selanjutnya subjek akan dilakukan tindakan invasif dengan pengambilan sampel darah vena sebanyak $3 \mathrm{cc}$ dan kemudian dilakukan proses pemisahan untuk memperoleh serum.

Pengukuran aktivitas enzim aspartate transaminase (AST) dilakukan berdasarkan prinsip metode Karmen, yang menggunakan enzim malate dehydrogenase sebagai indicator, yang mengkatalisis reaksi perubahan oksaloasetat menjadi malat dan oksidasi NADH menjadi $\mathrm{NAD}^{+}$.Sedangkan aktivitas enzim alanine transaminase (ALT) diukur menggunakan enzim laktat dehydrogenase (LDH) sebagai enzim indikator, yang mengkatalisis reaksi reduksi piruvat menjadi laktat dengan oksidasi $\mathrm{NADH}$ menjadi $\mathrm{NAD}^{+}$.Pengukiran aktivitas enzim AST dan ALT dilakukan di Laboratorium Klinik Fakultas Ilmu Kesehatan Universitas Muhammadiyah Palangkaraya, menggunakan instrumen fotometer $5010 \mathrm{~V}^{5+}$.

\section{HASIL DAN PEMBAHASAN}

Penelitian ini dilakukan untuk memberikan gambaran terkait efek dari konsumsi alkohol jangka panjang terhadap risiko penyakit hati.Konsumsi alcohol merupakan salah satu penyebab yang paling sering menyebabkan penyakit hati. Diagnosis penyakit hati alkoholik didasarkan pada bukti klinis dan hasil pemeriksaan penanda biokimia untuk kerusakan hati diantaranya enzim AST dan ALT, serta rasio AST/ALT yang banyak digunakan sebagai penanda terhadap diagnosis penyakit hati alkoholik (Shreevastva et al., 2017).

Subyek yang digunakan dalam penelitian ini adalah sebanyak 20 orang laki-laki penyalahguna alkohol di Jalan Mendawai Kecamatan Jekan Raya Kota Palangka Raya dengan usia antara $25-45$ tahun. Subjek dikategorikan berdasarkan usia, lama mengkonsumsi alcohol dan juga jumlah alkohol yang dikonsumsi/dosis. Kami mengelompokkan peminum alkohol berdasarkan dosis menjadi 2 kelompok yaitu peminum alkohol sedang (mengkonsumsi alkohol 
sebanyak 6,6-27,9 gram/hari) dan peminum alkohol berat (mengkonsumsi alkohol sebanyak >28 gram/hari). Karakteristik subyek di gambarkan pada tabel 1.

TABEL 1. Karakteristik Penyalahguna Alkohol

\begin{tabular}{|l|c|}
\hline \multicolumn{1}{|c|}{ Karakteristik } & $\mathbf{N}(\%)$ \\
\hline Umur & \\
\hline - $25-35$ & $5(25)$ \\
\hline - $36-45$ & $15(75)$ \\
\hline Lama Konsumsi & \\
\hline - $5-10 \mathrm{Th}$ & $14(70)$ \\
\hline - $>10 \mathrm{Th}$ & $6(30)$ \\
\hline Dosis & $7(35)$ \\
\hline - Peminum sedang & $13(65)$ \\
\hline - Peminum berat & \\
\hline
\end{tabular}

Berdasarkan kelompok umur pada tabel 1, terlihat subjek yang berusia 36 - 45 tahun lebih banyak yakni $80 \%$ atau 15 orang. Berdasarkan lama mengkonsumsi alkohol, sebanyak $70 \%$ subyek telah mengkonsumsi alkohol selama 5-10 tahun, dan 30\% subjek mengkonsumsi alkohol lebih dari 10 tahun. Sedangkan berdasarkan dosis alkohol yang dikonsumsi atau jumlah alkohol yang diminum setiap harinya, lebih banyak subyek sebagai peminum berat yakni $65 \%$ dan peminum sedang sebanyak $35 \%$.

Beberapa penelitian telah melaporkan hubungan antara konsumsi alkohol dengan peningkatan nilai AST dan ALT. Penelitian terhadap 1432 peminum alkohol, diperoleh nilai AST dan ALT yang meningkat moderat, dengan nilai AST $74 \pm 93$ U/L dan ALT 49 \pm 71 U/L. Peningkatan nilai akan semakin tinggi ketika konsentrasi alcohol dalam darah mencapai $>50 \mathrm{mg} / \mathrm{dL}$ (Wu et al., 2010).

Hasil penelitian kami terhadap aktivitas enzim AST diperoleh nilai rerata $129 \mathrm{U} / \mathrm{L}$ dengan rentang nilai AST adalah 47 - 243 U/L.Seluruh subyek memiliki nilai AST yang lebih tinggi dari nilai normal.Hasil yang lebih rinci terlihat pada tabel 2 .

Peminum alkohol dengan usia lebih tua dan konsumsi alkohol jangka panjang serta pada dosis yang lebih banyak, memiliki rerata nilai AST yang signifikan lebih tinggi ( $P$-value $<0.05)$. Di hati, AST terdapat pada sitosol (cAST) dan juga mitokondria (mAST) hepatosit.cAST dan mAST adalah isoenzim dan secara imunologis berbeda. mAST adalah isoenzim yang lebih umum dengan jumlahanya sekitar $80 \%$ dari total aktivitas AST di hati (Botros et al., 2013). Peningkatan kadar AST mungkin karena terjadi peningkatan permeabilitas membran sel, nekrosis sel dan kebocoran AST mitokondria (mAST) kedalam darah, yang disebabkan oleh konsumsi alkohol yang berlebihan (Arora et al., 2015).

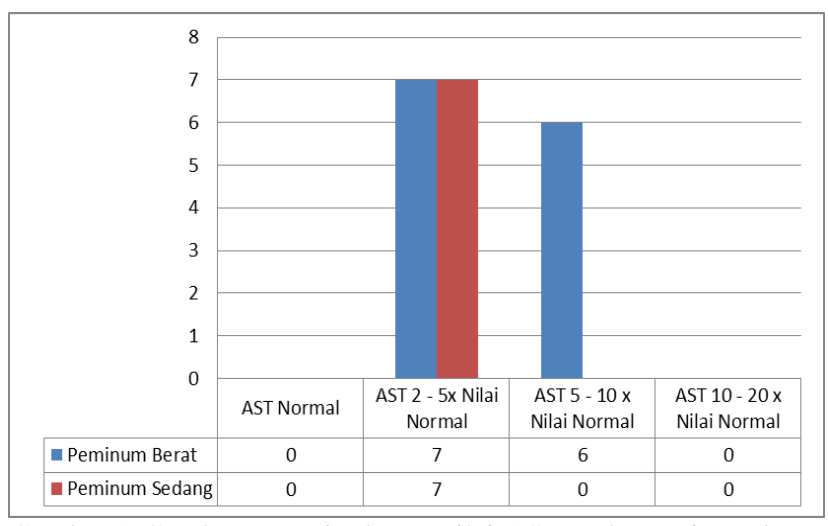

Gambar 1.Gambaran peningkatan nilai AST pada peminum berat dan sedang.

Pada gambar 1 terlihat sebanyak $46 \%$ atau 6 orang peminum alkohol berat, memiliki nilai AST 5-20 x nilai ambang batas atas normal (Upper Limit, UL) dan $54 \%$ atau 7 orang berada pada $2-5 \times$ UL. Sedangkan peminum sedang, semua subyek memiliki nilai AST 2-5 x UL. Menurut Hardjoeno (2003) peningkatan kadar AST $2-5$ x dari nilai normal dapat terjadi pada pada anemia hemolitik, metastase Ca hepatitis, pankreatitis akut dan perlemakan hati. Peningkatan $5-10 \quad \mathrm{x}$ dapat terjadi pada dermatomyositis dan sirosis hepatitis kronik.

Pengukuran aktivitas enzim ALT terhadap 20 sampel serum penyalahguna alkohol dijalan Mendawai kecamatan jekan raya kota palangkaraya, diperoleh nilai rerata ALT adalah $88 \mathrm{U} / \mathrm{L}$ dengan rentang nilai antara $34-175$ U/L. Hasil yang lebih rinci terlihat pada tabel 3 . 
BJMLT

ISSN : 26227-6111

TABEL 2. Hasil Pemeriksaan Aktivitas Enzim Aspartat Trasaminase (AST) pada Penyalahguna Alkohol

\begin{tabular}{|c|c|c|c|c|c|c|}
\hline \multirow{3}{*}{ Karakteristik } & \multirow{3}{*}{$\begin{array}{c}\text { Rerata } \pm \text { SD } \\
(\mathbf{U} / \mathbf{L})\end{array}$} & \multirow{3}{*}{$\begin{array}{c}\text { Rentang Nilai } \\
\text { (U/L) }\end{array}$} & \multicolumn{2}{|c|}{ Kadar AST } & \multirow{2}{*}{$\begin{array}{l}\text { Jumlah } \\
\text { sampel }\end{array}$} & \multirow{3}{*}{$P$-value } \\
\hline & & & Normal & $>$ Normal & & \\
\hline & & & $\mathbf{N}(\%)$ & $\mathbf{N}(\%)$ & $\mathbf{N}(\%)$ & \\
\hline \multicolumn{6}{|l|}{ Umur } & \multirow{3}{*}{$<0.001$} \\
\hline - $\quad 25-35$ & $63 \pm 21$ & $47-100$ & 0 & $5(25)$ & $5(25)$ & \\
\hline - $36-45$ & $150 \pm 62$ & $58-262$ & 0 & $15(75)$ & $15(75)$ & \\
\hline \multicolumn{6}{|l|}{ Lama Konsumsi } & \multirow{3}{*}{0.006} \\
\hline - $\quad 5-10 \mathrm{Th}$ & $99 \pm 49$ & $47-205$ & 0 & $14(70)$ & $14(70)$ & \\
\hline - $\quad>10 \mathrm{Th}$ & $198 \pm 50$ & $136-262$ & 0 & $6(30)$ & $6(30)$ & \\
\hline \multicolumn{6}{|l|}{ Dosis } & \multirow{3}{*}{$<0.001$} \\
\hline - Peminum sedang & $62 \pm 17$ & $47-100$ & 0 & $7(35)$ & $7(35)$ & \\
\hline - Peminum berat & $165 \pm 54$ & $90-262$ & 0 & $13(65)$ & $13(65)$ & \\
\hline
\end{tabular}

TABEL 3. Nilai ALT pada Peminum Alkohol

\begin{tabular}{|c|c|c|c|c|c|c|}
\hline \multirow{3}{*}{ Karakteristik } & \multirow{3}{*}{$\begin{array}{c}\text { Rerata } \pm \text { SD } \\
(\mathbf{U} / \mathbf{L})\end{array}$} & \multirow{3}{*}{$\begin{array}{c}\text { Rentang Nilai } \\
\text { (U/L) }\end{array}$} & \multicolumn{2}{|c|}{ Kadar ALT } & \multirow{2}{*}{$\begin{array}{l}\text { Jumlah } \\
\text { sampel }\end{array}$} & \multirow{3}{*}{$P$-value } \\
\hline & & & Normal & > Normal & & \\
\hline & & & $\mathbf{N}(\%)$ & $\mathbf{N}(\%)$ & $\mathbf{N}(\%)$ & \\
\hline \multicolumn{6}{|l|}{ Umur } & \multirow{3}{*}{0.017} \\
\hline - $\quad 25-35$ & $61 \pm 34$ & $34-116$ & $2(10)$ & $3(15)$ & $5(25)$ & \\
\hline - $36-45$ & $97 \pm 39$ & $45-175$ & 0 & $15(75)$ & $15(75)$ & \\
\hline \multicolumn{6}{|l|}{ Lama Konsumsi } & \multirow{3}{*}{$<0.001$} \\
\hline - $\quad 5-10 \mathrm{Th}$ & $68 \pm 24$ & $34-116$ & $2(10)$ & $12(60)$ & $14(70)$ & \\
\hline - $>10 \mathrm{Th}$ & $136 \pm 28$ & $102-175$ & 0 & $6(30)$ & $6(30)$ & \\
\hline \multicolumn{6}{|l|}{ Dosis } & \multirow{3}{*}{0.009} \\
\hline - Peminum sedang & $59 \pm 28$ & $34-116$ & $2(10)$ & $5(25)$ & $7(35)$ & \\
\hline - Peminum berat & $103 \pm 38$ & $58-175$ & 0 & $13(65)$ & $13(65)$ & \\
\hline
\end{tabular}

TABEL 4. Rasio AST/ALT pada Peminum Alkohol

\begin{tabular}{|c|c|c|c|c|}
\hline \multirow[b]{2}{*}{ Karakteristik } & Nilai AST & Nilai ALT & \multirow[b]{2}{*}{ Rasio AST/ALT } & \multirow[b]{2}{*}{$P$-value } \\
\hline & $\begin{array}{c}\text { Rerata } \pm \text { SD } \\
(\mathbf{U} / \mathbf{L})\end{array}$ & $\begin{array}{c}\text { Rerata } \pm \text { SD } \\
(\mathbf{U} / \mathbf{L})\end{array}$ & & \\
\hline \multicolumn{4}{|l|}{ Umur } & \multirow{3}{*}{0.027} \\
\hline $25-35$ & $63 \pm 21$ & $61 \pm 34$ & 1.2 & \\
\hline $36-45$ & $150 \pm 62$ & $97 \pm 39$ & 1.6 & \\
\hline \multicolumn{4}{|l|}{ Lama Konsumsi } & \multirow{3}{*}{0.859} \\
\hline $5-10 \mathrm{Th}$ & $99 \pm 49$ & $68 \pm 24$ & 1.5 & \\
\hline$>10 \mathrm{Th}$ & $198 \pm 50$ & $136 \pm 28$ & 1.5 & \\
\hline \multicolumn{4}{|l|}{ Dosis } & \multirow{3}{*}{0.002} \\
\hline Peminum sedang & $62 \pm 17$ & $59 \pm 28$ & 1.1 & \\
\hline - $\quad$ Peminum berat & $165 \pm 54$ & $103 \pm 38$ & 1.7 & \\
\hline RERATA KESELURUHAN & $129 \pm 67$ & $88 \pm 40$ & 1.5 & \\
\hline
\end{tabular}

Penelitian pada peminum alkohol yang berusia 36-45 tahun memiliki nilai ALT yang signifikan lebih tinggi dibandingkan usia 25 - 35 tahun. Lama konsumsi alkohol > 10 tahun, memiliki nilai yang signifikan lebih tinggi dibandingkan peminum $<10$ tahun. Sedangkan berdasarkan dosis alkohol yang 
dikonsumsi peminum berat memiliki nilai ALT yang signifikan lebih tinggi dibandingkan peminum sedang.Hal ini sesuai dengan penelitianShreevastvaet al. (2017) bahwa terjadi peningkataneALT pada orang yang konsumsi alkohol berat dibandingkan moderat/sedang.

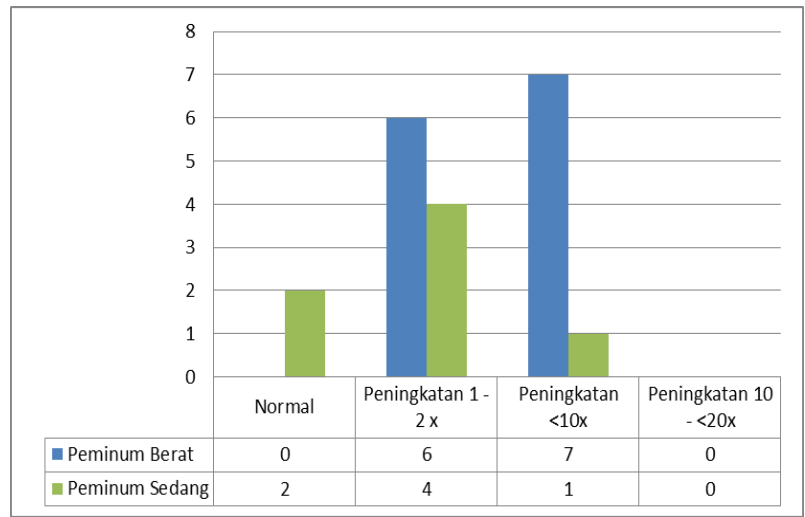

Gambar 2. Gambaran peningkatan nilai ALT pada peminum berat dan sedang.

Pada gambar 2 terlihat sebanyak 54\% atau 7 orang peminum alkohol berat, memiliki nilai ALT < 10x UL dan $46 \%$ atau 6 orang berada pada 1-2 x UL. Sedangkan peminum sedang, terdapat $29 \%$ atau 2 orang dengan ALT normal, $57 \%$ atau 4 orang peningkatan 1-2 x UL dan $14 \%$ atau 1 orang peningkatan $<10 \mathrm{UL}$.

Menurut Hardjoeno (2003) peningkatan kadar ALT 1 - 2 x dari nilai normal dapat terjadi pada infark miokard akut kongesti hepatik. Sedangkan peningkatan $<10 \mathrm{x}$ dapat terjadi pada sirosis hepatitis akut, hepatitis karena alkohol.

Hasil penelitian menunjukkan nilai AST dan ALT yang meningkat pada peminum alkohol, dengan rerata nilai ASTadalah $129 \pm 67 \mathrm{U} / \mathrm{L}$ yang lebih tinggi dibandingkan ALT adalah $88 \pm 40 \mathrm{U} / \mathrm{L}$. Hal ini sejalan dengan penelitian(Dakeishi et al., 2004), bahwa konsumsi alcohol dapat meningkatkan nilai AST lebih tinggi dibandingkan ALT, yang merupakan indikasi adanya kerusakan hapatoselular. Hal yang sama juga dilaporkan oleh Shreevastva (2017), dimana pada pasien penyakit hati alkoholik, nilai AST serum lebih tinggi dibandingkan ALT, dengan nilai AST dan ALT jarang melebihi 300 U/L. AST dan ALT merupakan enzim hepatoselular, jika terjadi gangguan/cidera pada hepatoseluler, enzim AST dan ALT akan terlepas ke dalam plasma, yang menyebabkan peningkatan aktivitas enzim-enzim ini. Pada kerusakan hati akut,jumlah ASTdidalam plasmaawalnya lebih tinggi dibandingkan ALT, karena jumlah AST di dalam sel hepatosit lebih tinggi dibandingkan ALT. Namun pada kerusakan hati kronis, jumlah ALT akan lebih tinggi dibandingkan AST karena metabolisme yang lambat serta waktu paruh ALT lebih lama dibandingkan AST (masing-masing 47 jam dan 17 jam), sehingga pada pasien dengan penyakit hati akan memiliki rasio AST/ALT (rasio De Ritis) kurang dari 1 (Xu et al., 2015).

Menurut Botros et al.(2013) asupan alkohol kronis dapat menyebabkan kerusakan mitokondria sehingga terjadi peningkatan pelepasan AST mitokondria dalam plasma. Selain itu, alkohol dapat menyebabkan malnutrisi termasuk defisiensi pyridoxal-5'phosphate (vitamin B6), yang merupakan koenzim untuk aktivitas AST dan ALT (Shreevastva et al., 2017). Sehingga rasio AST/ALT akan meningkat dengan nilai lebih dari 1.5 yang mengarah kepada hepatitis alkoholik(Botros et al., 2013). Hal ini juga sejalan dengan penelitian kami, dimana rerata nilai rasio AST/ALT adalah 1,5.

Menurut Singal et al (2018) diagnosis klinis hepatitis alkoholik (AH) ditentukan berdasarkan pada pasien dengan memburuknya perkembangan penyakit kuning yang cepat atau komplikasi penyakit hati, dengan bilirubin total serum> $3 \mathrm{mg} / \mathrm{dL}$; ALT dan AST di serum meningkat $>1,5$ kali batas atas normal tetapi <400 U/L dengan rasio AST/ALT> 1,5 serta riwayat penggunaan alkohol berat hingga 8 minggu sebelum timbulnya gejala; dan pengecualian penyakit hati lainnya.

Berdasarkan pada tabel 5 terlihat rerata nilai AST dan ALT signifikan lebih tinggi pada peminum berat dibandingkan pada peminum sedang, dan rasio de ritis pada peminum berat lebih tinggi yakni 1.64 dibandingkan pada peminum sedang yaitu 1.13. Dimana peminum berat dengan rasio de ritis sebesar 1,64 sudah mengarah pada penyakit hepatitis alkoholik.

\section{KESIMPULAN}

Terdapat peningkatan yang signifikan pada nilai AST dan ALT sertarasio AST/ALT (rasio De Ritis) pada pengkonsumsi alkohol di Jalan Mendawai Kota Palangka Raya, terutama peminum berat yang 
dicurigai memiliki risiko penyakit hati alkoholik karena senagian besar memiliki rasio AST/ALT (rasio De Ritis) > 1. Karena Rasio De Ritis dapat digunakan sebagai penanda penyakit hati alkoholik yang dapat diandalkan. Namun, penelitian lebih lanjut dengan ukuran sampel yang lebih besar atau memadai perlu dilakukan untuk dapat menerima konsep tersebut.

\section{DAFTAR PUSTAKA}

Arora, M. et al. 2015. Research Article Evaluation Of Ast / Alt Ratio In Patients Of Alcoholic Liver Disease. Bulletin of Pharmaceutical and Medical Sciences (BOPAMS). 3(1):. 30273030.

Botros, M. et al. 2013. The De Ritis Ratio: The Test of Time. Clin Biochem. 34: 117-130.

Dakeishi, M. et al. 2004. Effects of Alcohol Consumption on Hepatocellular Injury in Japanese Men. The Tohoku Journal of Experimental Medicine. 202(1): 31-39.

Dguzeh, U. et al. 2018. Alcoholism: A multisystemic cellular insult to organs. International Journal of Environmental Research and Public Health. 15(6).

Gao, B. and Bataller, R. 2011. Alcoholic Liver Disease: Pathogenesis and New Therapeutic Targets. Gastroenterology. 141(5): 1572-1585

Hardjoeno H. 2003. Interpretasi Hasil Tes Laboratorium Dan Diagnostic. Universitas Hasanudin : Makasar

King, MW. 2017. Ethanol Metabolism. Available at:https://themedicalbiochemistrypage.org/etha nol-metabolism.php diakses pada 15 April 2019

Mcdonald, H. et al. 2013. Comparative performance of biomarkers of alcohol consumption in a population sample of working-aged men in Russia: The Izhevsk Family Study. Addiction. 108(9): 1579-1589

Purbayanti, D., dan Saputra, N. A. R. 2017. Efek Mengkonsumsi Minuman Beralkohol Terhadap Kadar Triglisrida. Jurnal Surya Medika (JSM). 3(1): 75-81

Shreevastva, N. K., Pandeya, A. and Mishra, D. K. 2017. A study of AST : ALT ratio in alcoholic and nonalcoholic liver diseases', Saudi Journal of Medical and Pharmaceutical Sciences, 49 (29): 1047-1050.

Singal, A. K. et al. 2018. ACG clinical guideline: Alcoholic liver disease. American Journal of Gastroenterology. Nature Publishing Group, 113(2): 175-194

Steiner, J. L. and Lang, C. H. 2017. Alcohol, adipose tissue and lipid dysregulation. Biomolecules.

Thursz, M. et al. 2018. EASL Clinical Practice Guidelines: Management of alcohol-related liver disease. Journal of Hepatology. European Association for the Study of the Liver. 69(1): 154-181.

World Health Organisation and Management of Substance Abuse Team (2018) Global status report on alcohol and health 2018., World Health Organisation. doi: /entity/substance_abuse/publications/global_al cohol_report/en/index.html.

Wu, C.-Y. et al. 2010. Relationship Between Blood Alcohol Concentration and Hepatic Enzymes in an Emergency Department. Tzu Chi Medical Journal. Buddhist Compassion Relief Tzu Chi Foundation. 22(1): 24-28

Xu, Q., Higgins, T. and Cembrowski, G. S. 2015. Limiting the Testing of AST. American Journal of Clinical Pathology. 144(3): 423426 